\title{
Habenaria diphylla (Nimmo) Dalzell: A new addition to the orchid flora of Bilaspur district (Chhattisgarh), Central India
}

\author{
S. Vinodia, A. K. Dixit* \\ Department of Botany, Guru Ghasidas University, Bilaspur, Chhattisgarh, India
}

Received: 01.04.2017

Accepted: 03.05.2017

Published: 07.05.2017

*Address for correspondence:

A. K. Dixit, Department of Botany, Guru Ghasidas

University, Bilaspur,

Chhattisgarh, India.

E-mail: dixitak@live.com

\begin{abstract}
A detailed taxonomic description, distribution and illustrations are provided for easy and accurate identification. This finding has contributed towards the current knowledge on earthbound orchids in AABR. Another interesting discovery in AABR, This terrestrial orchid was found growing on specific white rocky slopes with sand rich in mica, covering two rocks with its two cordate leaves (i. e, diphylla) and tubers in between. Due to less rainfall in 2015-2016, the species showed severe decline in their number of population i.e, 5-10 individuals within $10 \mathrm{~m}^{2}$. Being very fragile to the changing environment, lead to local disappearance. It is proposed that several ephemeral orchids viz. Nervillia crociformis , H. digitata, Habenaria dentata along with H. diphylla are prone to local extinction in the Achanakmar Reserved forest which is a matter of serious concern.
\end{abstract}

KEY WORDS: Achanakmar-Amarkantak Biosphere Reserve, Habenaria diphylla, new record, Orchidaceae

\section{INTRODUCTION}

Genus Habenaria Willd. is the third largest genera in the family Orchidaceae with 876 species distributed in the tropical and subtropical regions of the world (Batista et al., 2013). Misra (2007) reported 84 species of this genus from India while Chowdhury et al. (2011) revealed 58 species with three varieties from India. Earlier in the $1890 \mathrm{~s}$, Sir J.D. Hooker enumerated 106 species of Habenaria in his book "The Flora of British India” (Hooker, 1890).

Blatter and McCann (1932) reported 25 species from Western Ghats while Chowdhery and Wadhwa (1984) enumerated 15 species of the genus from Himachal Pradesh. Totally 31 species were reported from Tamil Nadu (Henry et al., 1989). Pulliah (1997) noted 11 species from Andhra Pradesh. Cooke (1907) reported 17 species from Bombay Presidency whereas Satish Kumar and Manilal (2004) enumerated 25 species from Kerala. A total of 16 species have been reported from Odisha (Misra, 2004). A checklist of orchids enumerated 22 species including Habenaria diphylla from the state of Uttarakhand, Western Himalayas (Jalal et al., 2008). A checklist of 63 species of orchids were recorded from Chota Nagpur region of India includes 10 species of genus Habenaria including H. diphylla (Jalal et al., 2007).

From Chhattisgarh, $H$. diphylla was previously reported from Bastar district (Khanna et al., 2001) including 12 other species of genus Habenaria. In the report of biosphere reserve information series of Achanakmar-Amarkantak Biosphere Reserve (AABR), 25 species of family Orchidaceae were reported, of which 3 species were of the genus Habenaria i.e., Habenaria dentata, Habenaria digitata, Habenaria furcifera (BRIS, 2010). From the Kanger valley National Park of Chhattisgarh, 5 species were reported by Kotia et al. (2013) whereas 2 species were noted by Murti and Panigrahi (1999) in Flora of Bilaspur from Achanakmar i.e., $H$. digitata and $H$. dentata whereas 7 species were recorded from East Nimar region of Madhya Pradesh (Mujaffar et al., 2013).

\section{MATERIALS AND METHODS}

The present study was carried out in AABR. It occupies an area of 205898 ha. AABR is extended across Chhattisgarh State to Madhya Pradesh of Central India between latitude $22^{\circ} 15^{\prime}$ to $20^{\circ} 58^{\prime}$ North and longitude $81^{\circ} 25^{\prime}$ to $82^{\circ} 5^{\prime}$ 


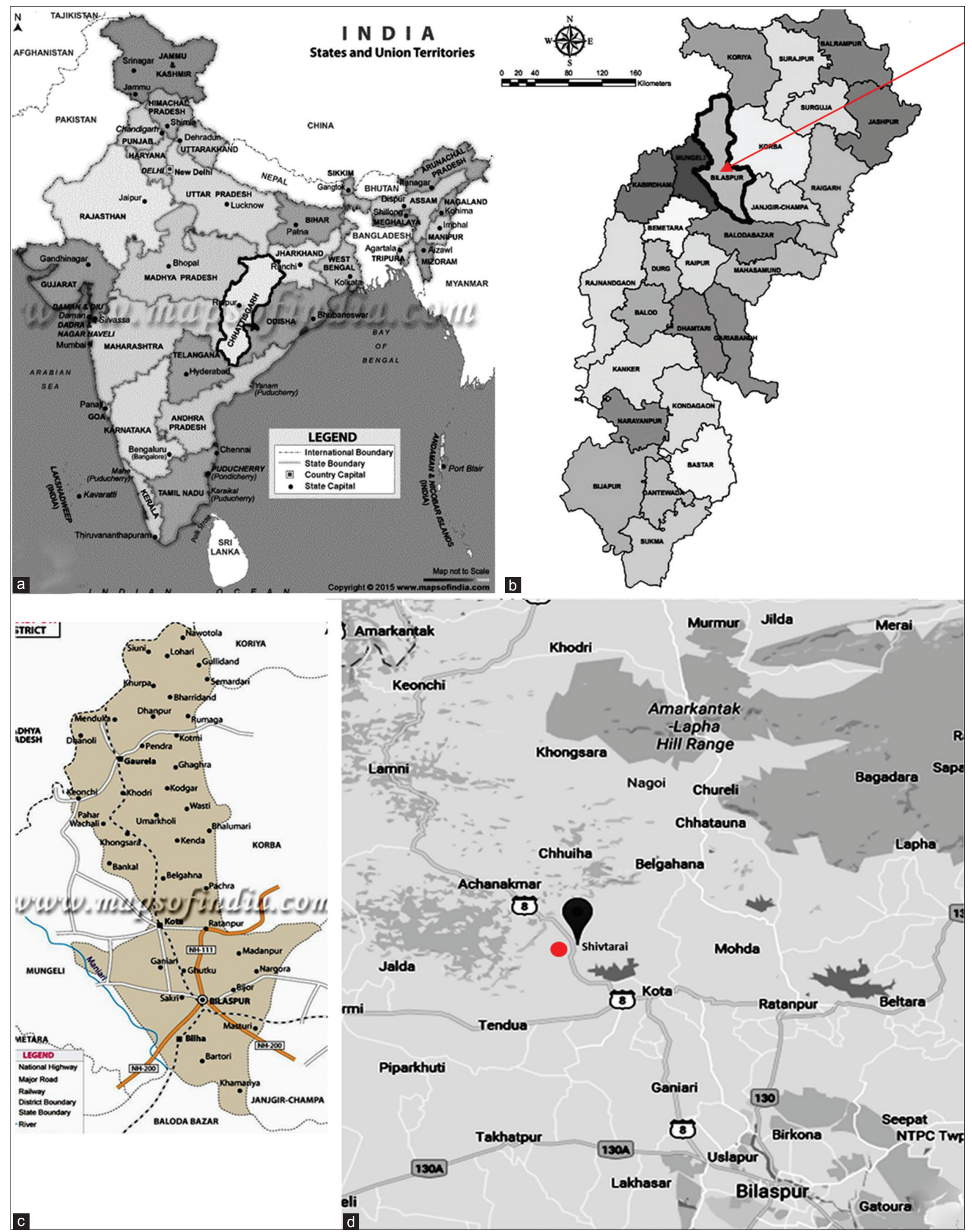

Figure 1: (a-d) Map of study site (Shivtarai, Achanakmar-Amarkantak Biosphere Reserve) in Bilaspur district (Chhattisgarh) (Source www.mapsofindia.com) 
East. Buffer zone that stretched out in Shivtarai (collection area) falls under Bilaspur district (Figure 1). The forest is dominated with $\mathrm{Sal}$ and $\mathrm{Sal}$ mixed vegetation. Climate here is monsoonal type.

During field exploration in various parts of AABR, plant species were collected in flowering condition in the month of September 2015. Field note, date, locality and brief

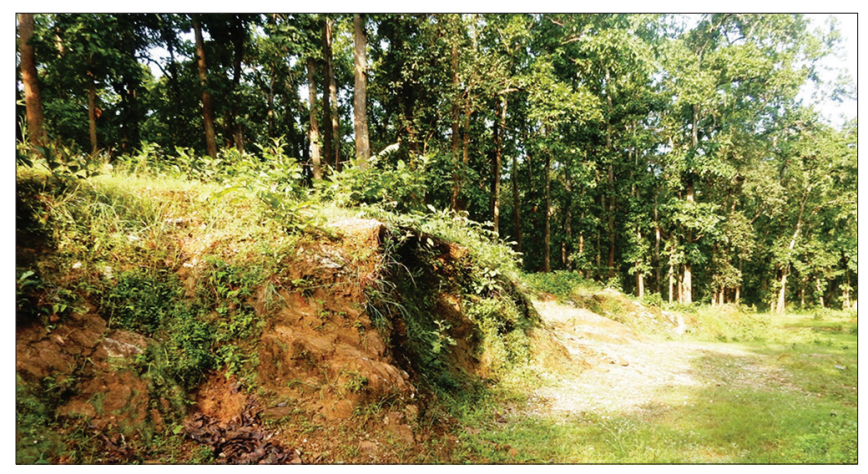

Figure 2: Habitat of Habenaria diphylla (Nimmo) Dalzell identification features were noted. Based on the available literature (Khanna et al., 2001; Hooker, 1890), the taxon was identified as H. diphylla (Nimmo) Dalzell and voucher specimen in the form of herbarium sheet (Jain and Rao, 1977) have been deposited in the Department of Botany (Gurughasidas Vishwavidyalaya), Bilaspur (Chhattisgarh). A brief description with illustrations (plage 1) and conservation status is provided in this paper. A key to all the 12 species reported earlier from Chhattisgarh is provided (Table 1).

\section{Taxonomic description}

H. diphylla (Nimmo) Dalz. In Hook's J. Bot. 2: 262.1850; Hook.f., Fl. Brit. India 6:151.1890; Prain: 1033; Haines: 1158: Fischer: 1471; Tiwari and Maheshwari: 435; Misra, 1982b. p. 24; 1990a. p. 64; 1996a. p. 30; 2000. p. 26.

Terrestrial monocot herbs, $10-30 \mathrm{~cm}$ tall. Tubers ovoid to ellipsoid, stem erect green, glabrous, leaves-2, opposite,

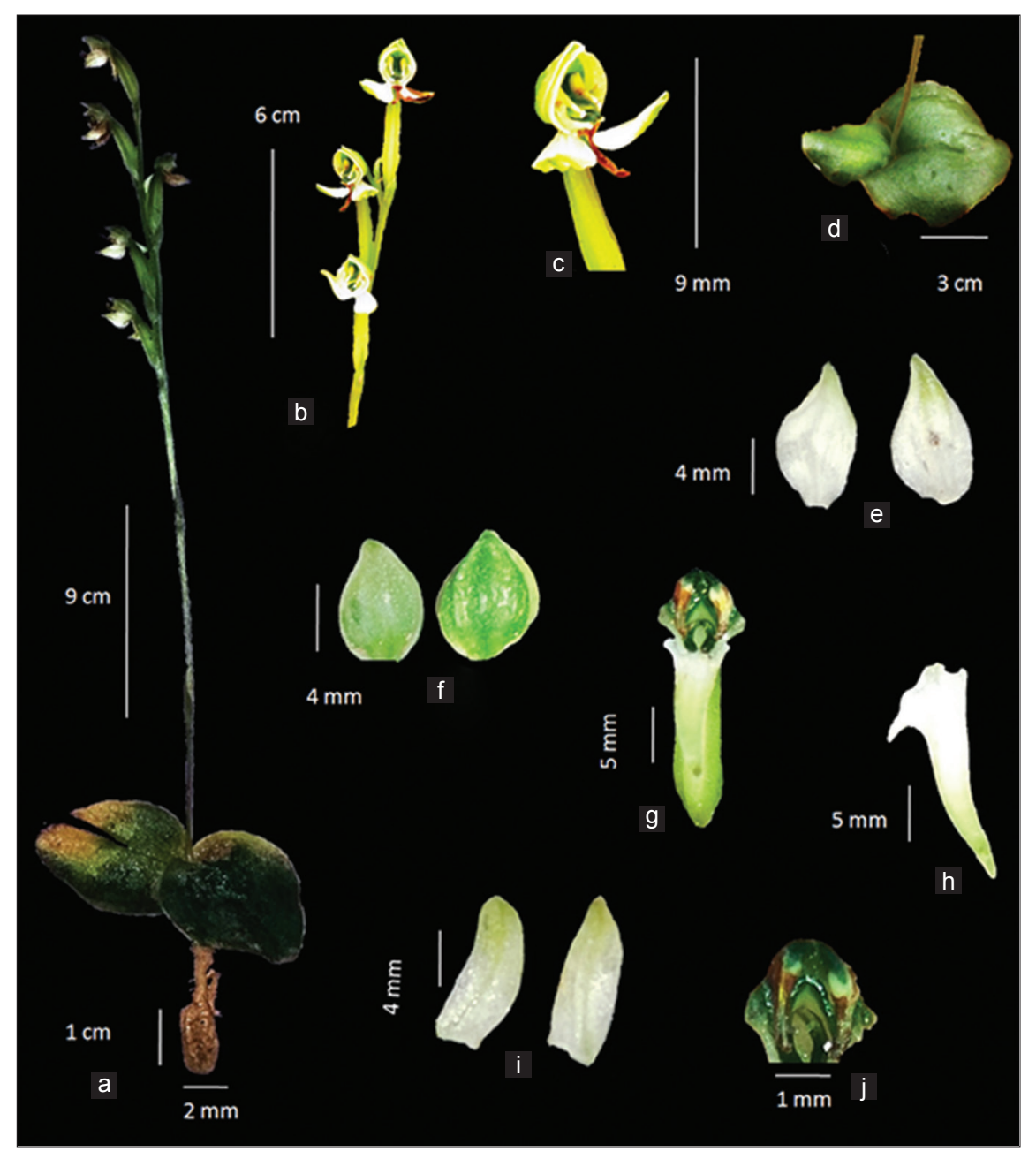




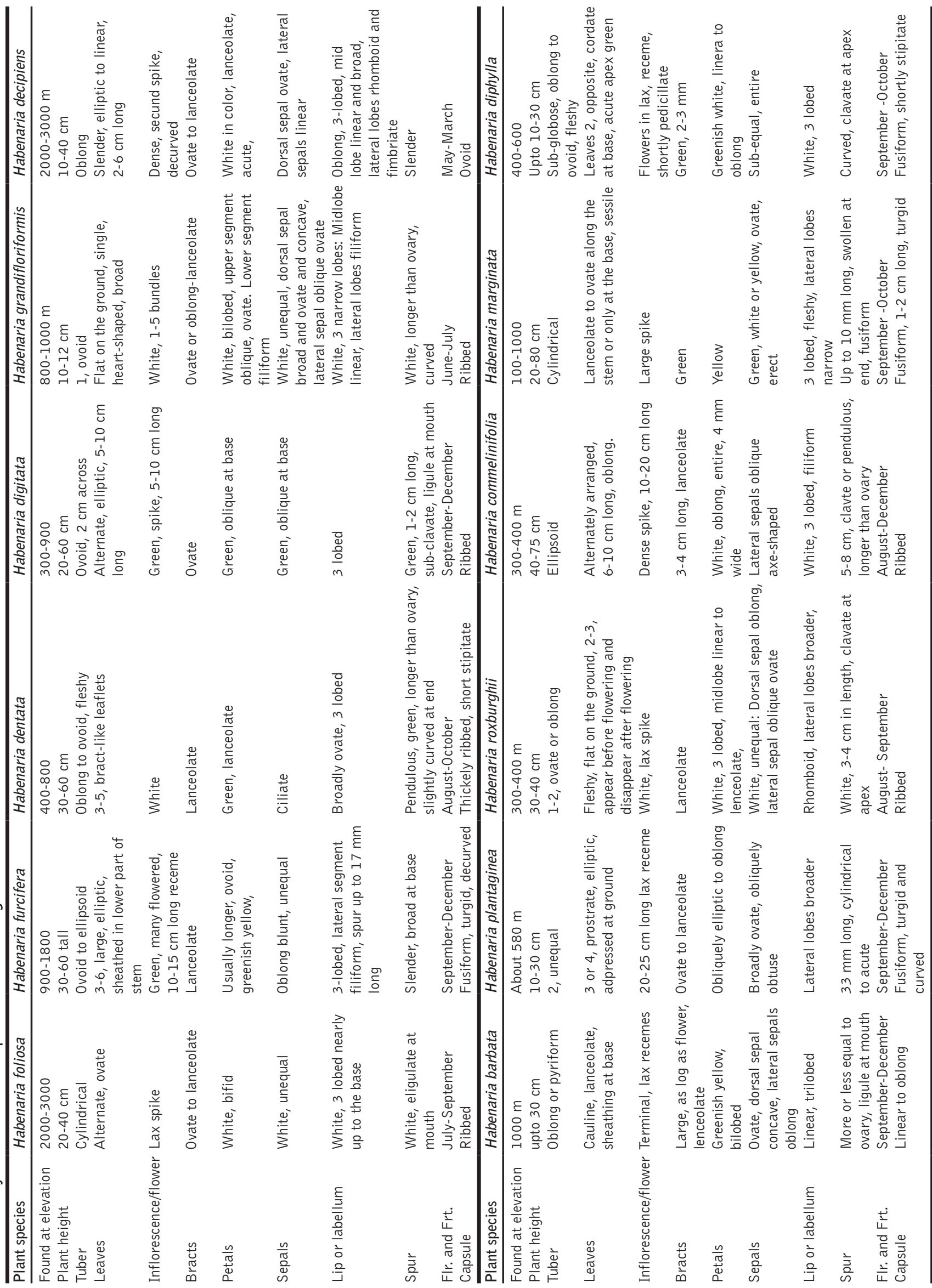


attached to the ground, cordate at base, acute apex, 3-6 bract-like green leaves along the stem, acute apex. Inflorescence - spike, flowers in lax, many flowered, 6-8 cm long recemes, dorsal sepals pale green, lateral sepals white, small, dorsal sepals hooked with petals, concave, greenish white. Labellum 3-lobed: Lateral lobes filiform, mid lobe acute. Spur greenish white, curved, acute at apex and slightly broad at mouth. Pollinia yellow, capsule fusiform.

- Flr. - Frt. : September-October

- Locality: Shivtarai, District - Bilaspur, AABR (Chhattisgarh)

- Specimen examined: India, Chhattisgarh, AABR, Shivtarai, latitude - 22;23;1.1459, longitude $81 ; 53 ; 27.99599$, altitude 498.2, date of collection September 07, 2015, S Vinodia, SHIV20/02 / GGV / BOT

- Habitat and ecology: In moist deciduous forest (Fig 2), on the rocky hill with sandy soil, with average shade, found growing along with other species viz. Iphigenia indica (L.) A. Gray ex Kunth, Curcuma ceasia Roxb., Curcuma longa, Globba sp., Orthosiphon sp., Elephantopus scaber, Eriocolon quinquangulare, etc. at the elevation between 400 and $500 \mathrm{~m}$.

- Distribution: Nepal, Bhutan, Bangladesh, China, Myanmar, Thailand, Philippines, India (Himachal Pradesh and Uttarakhand, Kerela, Tamil Nadu, West Bengal, Karnataka and Odisha).

\section{DISCUSSION}

H. diphylla has been reported from Bilaspur district (AABR) for the first time showing narrow range of distribution with lesser number of individuals and considered as rare. So far, in Chhattisgarh state, present species was reported from Bastar (Khanna et al., 2001) and it has been recollected now after 15 years from Bilaspur. Also, it assessed as "rare" in Western Himalaya and Odisha (Jalal, 2012, Misra 2004). Some morphological changes have also been observed like variation in plant height and population size was found to be reduced due to environmental changes which affect the structure and phenology. Similar observations have been made by Gattoo and Ahmad (2013), Reddy et al. (2013), Barman and Devadas (2013), Cribb et al. (2003). Investigated plant species has been very sensitive to the changing environment and prone to high risk of extinction in the near future. Anthropogenic activity as well as cattle grazing in buffer zone is the key cause of its rarity. Therefore, habitat protection of this rare plant is urgently needed for healthy native habitat.

\section{ACKNOWLEDGMENTS}

I would like to thank CCF, AchanakmarTiger Reserve for providing necessary facilities and permission. Thanks are also extended to my colleagues for their support during field visit.

\section{REFERENCES}

Barman D, Devadas R. Climate change on orchid population and conservation stratigies: A review. J Crop Weed 2013;9:1-12.

Batista JA, Karina SB, MarinaWF, de Faria K, Aline P, Gerardo JR, et al. Molecular phylogenetics and morphological reappraisal of the Platanthera clade (Orchidaceae: Orchidinae) prompts expansion of the generic limits of Galearis and Platanthera. Ann Bot 2013;104:431-45.

Blatter E, McCann C. Revision of the flora of Bombay presidency Orchidaceae (Parts 16-19). J Bombay Nat Hist Soc 35:254-736; 36:13-28.

BRIS. Achanakmar Amarkantak Biosphere Reserve. Vol.2. Jabalpur, MP:TFRI; 2010. p. 105.

Chowdhery HJ, Wadhwa BM. Orchidaceae. In: Flora of Himachal Pradesh, Analysis. Vol. 3. Calcutta: BSI; 1984. p. 680-93.

Chowdhury S, Mukherjee SK, Chowdhery HJ. Distribution and diversity of the genus Habenaria Willdnow. (Orchidaceae) in India. In: Ghosh C, Das AP, editors. Recent Studies in Biodiversity and Traditional Knowledge in India. Malda, India: Gour College; 2011. p. 81-90.

CookeT. The Flora of the presidency of Bombay. Vol. 2. London: Taylor \& Francis; 1907. p. 713-23.

Cribb PJ, Kell SP, Dixon KW, Barrett RL. Orchid conservation: A global perspective. In. Orchid Conservation. Kota Kinabalu, Sabah: Natural History Publishing; 2003. p. 1-4.

Gattoo AA, Ahmad MA. A Review on orchids in India and their conservation. Int J Adv Res 2013;1:5-7.

Henry AN, ChitraV, Balakrishnan NP.The Flora of Tamil Nadu. Calcutta, India: BSI; 1989.

Hooker JD. Orchidaceae. In: The Flora of British India. Vol.6. London: L. Reeve \& Co.; 1890. p. 804.

Jain SK, Rao RR. A Handbook of Field and Herbarium Methods. New Delhi:Today andTomorrow's Printers and Publishers; 1977.

Jalal JS, Kumar P, Rawat GS, Pangtey YP. Orchidaceae, Uttarakhand, Western Himalaya, India. Check List 2008;4:304-20.

Jalal JS, Kumar P, Rawat GS. Orchidaceae, Chota Nagpur, State of Jharkhand, India. Check List 2007;3:297-304.

Jalal JS. Status, threatened \& conservation strategies for orchids of Western Himalaya, India. JThreat Taxa 2012;4:3401-9. 
Khanna KK, Singh NP, Mudgal V, Dixit RD. Flora of Madhya Pradesh. Vol. 3. Calcutta: Botanical Survey of India; 2001. p. 43-4.

Kotia A, Kumar P, Tiwari UL, Jalal JS, Prasad AN. Orchid diversity and distribution in Kanger National Park (Chhattisgarh). J Econ Taxon Bot 2013;37:207-15.

Kumar CS, Manilal KS. A Catalogue of Indian Orchids. Dehradun: Bisen Singh Mahendra Pal Singh; 1994.

Misra S. Orchids of Orissa. Dehradun: Bishen Singh Mahendra $\mathrm{Pal} ; 2004$.

Misra SK. Orchids of India - A Glimpse. Dehradun, India: Bishen
Singh Mahendra Pal Singh; 2007. p. 302.

Mujaffar S, Mishra S, Deoda VS, Moinuddinb S, Mustakimb S. Orchid species diversity of East Nimar, Madhya Pradesh. Int J Plant Anim Environ Sci 2013;4:222-30.

Murti SK, Panigrahi GP. Flora of Bilaspur. Calcutta: BSI; 1999.

Pulliah T. Flora of Andhra Pradesh. Vol. 3. Jodhpur, India: Scientific Publishers; 1997.

Reddy S, RajuV, Reddy KN, Rao KS, Bahadur B. Orchid wealth of Andhra Pradesh, India; 2013. Available from: http: / / www.researchgate.net/publication/262007934. [Last accessed on 2015 Dec 21]. 